\title{
PENGARUH JENIS ANYAMAN DAN FRAKSI VOLUME SERAT TERHADAP KEKUATAN BENDING DAN IMPACT KOMPOSIT SERAT RAMI DENGAN MATRIK RESIN POLYESTER
}

\author{
Achmad Zainuri*, Sinarep, Agus Purwoko dan Nurkaliwantoro \\ Teknik Mesin Fakultas Teknik Universitas Mataram, \\ *Email: achmadzainuri70@yahoo.co.id.
}

\begin{abstract}
Abstrak
Tujuan dari penelitian ini adalah untuk mengetahui pengaruh jenis anyaman yang digunakan dalam setiap resin komposit yang diperkuat serat rami poliester terhadap ketangguhan dan kekuatan lentur. Dalam penelitian ini, bahan yang digunakan adalah serat rami yang telah dibuat anyaman dengan variasi tiga fraksi volume 10\%, 20\%, dan 30\%. Uji impak Charpy dilakukan dengan standar ASTM D 5942 -96 dan uji bending dengan ASTM D 790. Dari hasil analisis varian dua arah menunjukkan pengaruh jenis anyaman dan fraksi volume serat secara signifikan terhadap kekuatan impak dan kekuatan tekuk, sedangkan untuk interaksi antara keduanya, tetapi tidak ada interaksi yang signifikan. Dari hasil pengujian kekuatan impak menunjukkan bahwa nilai maksimum pada jenis anyaman 1 dengan fraksi volume serat $30 \%$ dengan kekuatan impak ratarata $9,91 \mathrm{KJ} / \mathrm{m}^{2}$ sedangkan nilai terendah pada jenis anyaman 3 dengan fraksi volume serat $10 \%$ dengan kekuatan impak rata-rata $7,35 \mathrm{KJ} / \mathrm{m}^{2}$. Dari hasil uji kuat lentur menunjukkan bahwa nilai maksimum pada jenis anyaman 2 dengan fraksi volume 30\% dengan rata-rata kekuatan lentur $N /$ $\mathrm{mm}^{2}$ sedangkan skor terendah 18,00 pada jenis anyaman 1 dengan fraksi volume serat 10\% dengan kekuatan lentur rata-rata $11,18 \mathrm{~N} / \mathrm{mm}^{2}$.
\end{abstract}

Kata kunci: Jenis anyaman, ketangguhan impact, kekuatan lentur, komposit

\section{PENDAHULUAN}

Tanaman rami adalah tanaman serat nabati yang menghasilkan serat dari kulit kayu. Tanaman rami pada umumnya terdapat di daerah Asia seperti China, Kamboja, Thailand, Vietnam, Filipina, Taiwan, India, Banglades, Pakistan, dan juga Indonesia. Negara penghasil rami dalam jumlah besar pada waktu ini adalah China, Filipina, Banglades dan Brasil. Jenis tanaman rami dapat tumbuh dengan mudah di daerah tropis maupun sub-tropis hingga $40^{\circ}$ LU/LS. Di daerah tropis, kebun rami yang ideal adalah pada ketinggian sekitar 400 sampai 1200 meter di atas permukaan laut (catatan: tersedia cukup air). dengan suhu $20^{\circ} \mathrm{C}-28^{\circ} \mathrm{C}$ dan dengan curah hujan minimal $90 \mathrm{~mm} /$ bulan. Tanah bertekstur ringan dengan $\mathrm{PH}$ berkisar 4,8 - 6,4. Kecepatan angin tidak melebihi $30 \mathrm{Km} / \mathrm{jam}$ untuk menahan supaya tanaman tidak roboh (Supratman, 2009).

Saat ini serat alam mulai mendapatkan perhatian yang serius dari para ahli material komposit karena beberapa alasan sebagai berikut:

- Serat alam memiliki kekuatan spesifik yang tinggi karena serat alam memiliki berat jenis yang rendah.

- Serat alam ramah lingkungan karena mudah terurai, mudah diperoleh dan merupakan sumber daya alam yang dapat diolah kembali, harganya relatif murah dan tidak beracun.

Arah serat penguat menentukan kekuatan komposit. Kekuatan maksimum serat sangat dipengaruhi oleh arah serat. Ada tiga jenis arah serat yaitu serat searah, serat dua arah dan serat acak/isotropik. Anyaman merupakan salah satu arah serat dua arah. Anyaman yang berbeda memiliki ikatan antar setiap serat arah pertama dan arah kedua ini mempengaruhi nilai tegangan yang terjadi apabila dikenai beban.

Dari latar belakang di atas timbul suatu pemikiran untuk melakukan penelitian tentang pengaruh penggunaan jenis anyaman dan fraksi volume serat pada serat rami terhadap kekuatan impact dan bending.

\section{TINJAUAN PUSTAKA}

Serat rami memiliki keunggulan dibandingkan serat-serat yang lain seperti kekuatan tarik, daya serap terhadap air, tahan terhadap kelembaman dan bakteri, tahan terhadap panas, serat rami memiliki peringkat nomor dua setelah sutra dibandingkan dengan serat alam yang lain, lebih ringan dibandingkan serat sintetis dan ramah lingkungan. Arah serat penguat menentukan kekuatan komposit, kekuatan maksimum serat sesuai dengan arah 
serat. Arah serat juga mempengaruhi jumlah serat yang dapat diisikan ke dalam matriks. Makin cermat penataannya, makin banyak penguat yang dimasukkan, bila sejajar berpeluang sampai $90 \%$; bila separuh dan saling tegak lurus peluangnya $75 \%$; dan tatanan acak hanya memberikan peluang pengisian 15\%-50\% (Feldman dan Hartomo, 1995).

Perekat Polyester Resin merupakan jenis material polimer thermosetting, yaitu jenis material dimana terbentuknya ikatan dibantu oleh panas, katalis atau gabungannya. Matriks ini dapat menghasilkan keserasian matriks penguat dengan mengontrol faktor jenis dan jumlah komponen, katalis, waktu dan suhu. Sifatnya tahan creep, memadai selaku perekat terbeban berat, serta tahan terhadap kondisi ekstrem panas, radiasi, kelembaman dan tahan kimia (Hartomo, 1992).

Larutan $\mathrm{NaOH}$ bersifat dapat merusak media karena memiliki ion natrium yaitu suatu kation yang sangat kuat bereaksi dengan $\mathrm{OH}$ yang memiliki konsentrasi tinggi sehingga memiliki basa kuat dari basa lainya jika berada dalam larutan air. Reaksi Natrium Hidroksida $(\mathrm{NaOH})$ dalam air : $\mathrm{NaOH} \rightarrow \mathrm{Na}^{+}+\mathrm{OH}^{-}$. Larutan ini digunakan sebagai medium dengan konsentrasi tertentu untuk melarutkan lapisan lilin pada permukaan serat, sehingga permukaan serat bersih dari lapisan lilin tersebut dan permukaan serat menjadi kasar agar dihasilkan ikatan yang lebih baik antara serat dan matriksnya (Supratman, 2009).

\section{LANDASAN TEORI}

\section{Uji Impact}

Untuk pengujian ini digunakan sebuah mesin dimana suatu batang dapat berayun dengan bebas seperti pada Gambar 1 di bawah ini. Pada ujung batang dipasang pemukul yang diberi beban. Batang uji diletakkan di bagian bawah mesin dan takikan tepat berada pada bidang lintasan pemukul. Pada pengujian ini bandul pemukul dinaikkan pada ketinggian tertentu $\mathrm{H}$, pada posisi ini pemukul memiliki energi potensial sebesar WH. Dari posisi ini pemukul dilepaskan dan berayun bebas, memukul batang uji hingga patah, dan pemukul masih terus berayun sampai ketinggian $\mathrm{H}$, pada posisi ini sisa energi potensial adalah WH. Selisih antara energi awal dengan akhir adalah energi yang digunakan untuk mematahkan batang uji.

Hasil pengukuran dengan impact test ini tidak dapat digunakan untuk keperluan suatu desain, ia hanya dapat digunakan untuk membandingkan suatu sifat bahan dengan bahan yang lain.

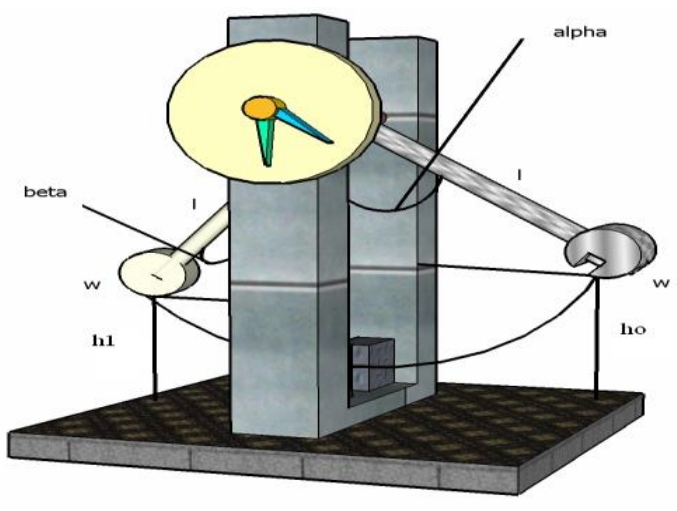

Gambar 1. Alat uji impact.

Untuk mengukur data hasil uji impact digunakan rumus-rumus sebagai berikut:

$$
\begin{aligned}
\mathrm{E}_{\text {awal }} & =\mathrm{M} \cdot \mathrm{g} \cdot \mathrm{h}_{\mathrm{o}} \\
\mathrm{E}_{\text {akhir }} & =\mathrm{M} \cdot \mathrm{g} \cdot \mathrm{h}_{1} \\
\mathrm{~h}_{\mathrm{o}} & =1-\ell \cos \alpha \\
\mathrm{h}_{1} & =1-\ell \cos \beta \\
\Delta \mathrm{E} & =\mathrm{E}_{\text {awal }}-\mathrm{E}_{\text {akhir }} \\
& =\mathrm{M} \cdot \mathrm{g} \cdot \mathrm{h}_{0}-\mathrm{M} \cdot \mathrm{g} \cdot \mathrm{h}_{1} \\
& =\mathrm{M} \cdot \mathrm{g}\left(\mathrm{h}_{0}-\mathrm{h}_{1}\right)
\end{aligned}
$$

Dimana:

Sehingga:

$$
\mathrm{W} \quad=\mathrm{M} \cdot \mathrm{g}
$$

$$
\begin{array}{ll}
\Delta \mathrm{E} & =\mathrm{W} \cdot \ell(\cos \beta-\cos \alpha) \\
\mathrm{A} & =(\mathrm{b}-\mathrm{H}) \mathrm{xh}
\end{array}
$$

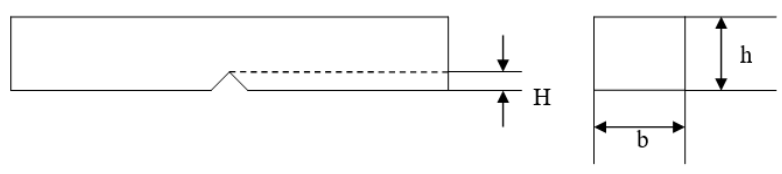

\section{Gambar 2. Dimensi spesimen}

Dimana :

$$
\begin{array}{cl}
\Delta \mathrm{E} & =\text { Tenaga Patah }(\mathrm{J}) \\
& \alpha=\text { Sudut Bandul Sebelum Diayunkan } \\
\mathrm{A} & =\text { Luas Penampang }\left(\mathrm{m}^{2}\right) \\
& \beta=\text { Sudut Bandul Setelah Diayunkan } \\
\mathrm{W} & =\text { Beban Kejut }\left(\mathrm{Kg} \mathrm{m} / \mathrm{s}^{2}\right) \\
& \quad \mathrm{M}=\operatorname{Massa} \text { Bandul }(\mathrm{Kg}) \\
\mathrm{b} & =\text { Lebar Spesimen }(\mathrm{m}) \\
& \mathrm{g}=\text { Kecepatan Gravitasi }\left(\mathrm{m} / \mathrm{s}^{2}\right) \\
\mathrm{H} & =\text { Takik Pada Spesimen }(\mathrm{m}) \\
& \mathrm{h}=\text { Tebal Spesimen }(\mathrm{m}) \\
\ell & =\text { Panjang Lengan Bandul }(\mathrm{m})
\end{array}
$$



Harga kekuatan $=\frac{\text { TenagaPatah }}{\text { Luas Penampang }}$

\section{Uji Bending}

Dengan standar ASTM D790 kekuatan bending dapat diperoleh menggunakan rumus :

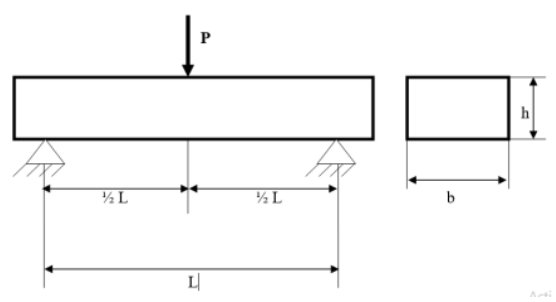

Gambar 2. Spesimen uji bending

$$
\sigma=\frac{M \cdot y}{I}
$$

Dimana:

$$
\begin{gathered}
M=\frac{P}{2} \cdot \frac{1}{2} L \quad I=\frac{b h^{3}}{12} \\
y=\frac{1}{2} \cdot h
\end{gathered}
$$

Sehingga:

$$
\begin{aligned}
\sigma_{B} & =\frac{\frac{P}{2} \cdot \frac{1}{2} L \cdot \frac{1}{2} h}{\frac{b h^{3}}{12}} \\
\sigma_{B} & =\frac{3}{2} \cdot \frac{P L}{b h^{2}}
\end{aligned}
$$

dimana:

$\mathrm{P}=$ Beban maksimum terpakai $(\mathrm{Kg})$

$\mathrm{L}=$ Panjang specimen yang ditumpu

(mm)

$\mathrm{b}=$ Lebar specimen $(\mathrm{mm})$

$\mathrm{h}=$ Ketebalan specimen $(\mathrm{mm})$

\section{METODE PENELITIAN}

\section{Alat dan Bahan:}

Alat yang digunakan dalam penelitian ini adalah sebagai berikut :

a) Alat uji impact (jenis charpy) dan bending.

b) Stopwatch.

c) Cetakan serat dan resin polyester

d) Pemukul dan landasan untuk menumbuk kulit sehingga berbentuk serat

e) Gunting / silet. f) Spidol.

g) Alat pemilin.

h) Gergaji dan gerinda.

i) Jangka sorong / mistar.

j) Kamera, scanner untuk dokumentasi.

k) Gelas ukur.

1) Timbangan digital.

m) Isolasi

Adapun bahan dalam penelitian ini antara lain

a) Resin polyester

b) Serat rami.

c) Larutan $\mathrm{NaOH}$ dengan konsentrasi $5 \%$.

d) Air.

e) Penggilap keramik (MAA).

\section{Proses Pembuatan Specimen}

Anyaman serat dipotong sesuai dengan ukuran panjang dan lebar specimen yang akan dibuat. Jenis anyaman dapat dilihat seperti pada Gambar 3. Selanjutnya anyaman serat dilapisi dengan resin polyester pada bagian atas dan bawah seperti terlihat pada Gambar 4.
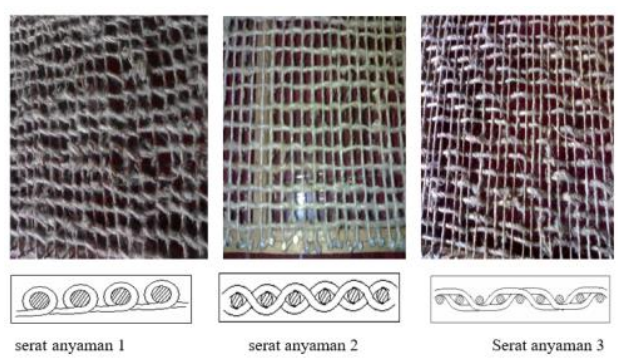

Gambar 3. Jenis anyaman serat rami

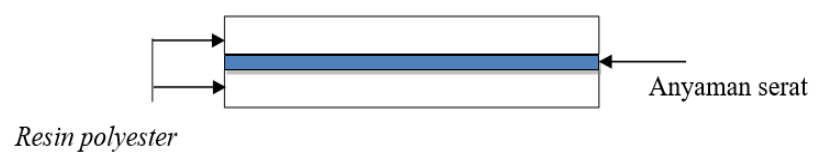

Gambar 4 Pembuatan specimen

\section{Specimen Uji Impact}

Pengujian impact untuk mengetahui ketangguhan impact. Dimensi specimen seperti pada Gambar 5 di bawah ini.

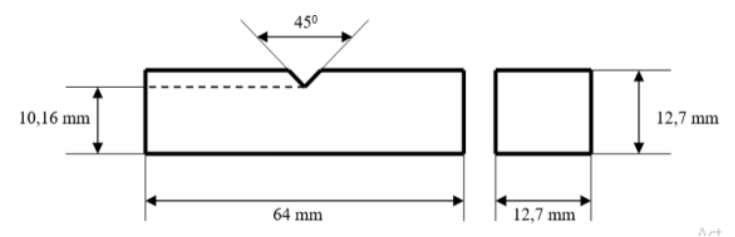

Gambar 5. specimen uji impact ASTM D 5942 -96 


\section{Specimen Uji Bending}

Pengujian bending dilakukan untuk mengetahui kekuatan bending. Dimensi specimen dapat dilihat pada Gambar 6 di bawah ini.

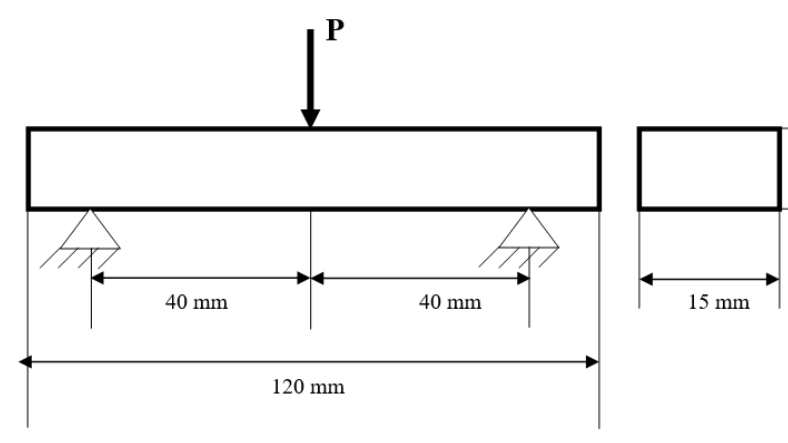

Gambar 6. Spesimen uji bending ASTM D790

\section{HASIL DAN PEMBAHASAN \\ Kekuatan impact}

Tabel 1. Data kekuatan impact rata-rata.

\begin{tabular}{|c|c|c|c|}
\hline \multirow[t]{2}{*}{$\begin{array}{c}\text { Jenis } \\
\text { anyaman }\end{array}$} & \multicolumn{3}{|c|}{$\begin{array}{c}\text { Kekuatan impact }\left(\mathrm{KJ} / \mathbf{m}^{2}\right) \\
\text { variasi fraksi volume serat } \\
(\%)\end{array}$} \\
\hline & $10 \%$ & $20 \%$ & $30 \%$ \\
\hline \multirow[t]{3}{*}{ Anyaman 1} & 8,083 & 9,583 & 9,583 \\
\hline & 7,737 & 8,660 & 10,564 \\
\hline & 7,160 & 8,948 & 9,583 \\
\hline Total & 22,979 & 27,191 & 29,730 \\
\hline Rata-rata & 7,660 & 9,064 & 9,910 \\
\hline \multirow[t]{3}{*}{ Anyaman 2} & 8,083 & 8,948 & 10,448 \\
\hline & 6,525 & 8,371 & 10,737 \\
\hline & 8,083 & 8,660 & 8,083 \\
\hline Total & 22,691 & 25,979 & 29,268 \\
\hline Rata-rata & 7,564 & 8,660 & 9,756 \\
\hline \multirow[t]{3}{*}{ Anyaman 3} & 7,448 & 7,448 & 8,948 \\
\hline & 6,525 & 8,083 & 8,948 \\
\hline & 8,083 & 7,737 & 6,525 \\
\hline Total & 22,056 & 23,268 & 24,422 \\
\hline Rata-rata & 7,352 & 7,756 & 8,140 \\
\hline
\end{tabular}

Data hasil eksperimen yang menunjukkan hubungan antara variasi jenis anyaman dan variasi volume serat terhadap kekuatan impact dapat dilihat pada Tabel 1 dan grafik pada Gambar 7. Dari grafik pada Gambar 7 dapat dilihat bahwa kekuatan impact rata-rata paling tinggi terjadi pada anyaman 1 dengan fraksi volume serat $30 \%$ sebesar $9,91 \mathrm{KJ} / \mathrm{m}^{2}$.

Hal ini disebabkan karena jenis anyaman yang memiliki bentuk yang melingkar penuh pada arah serat yang tegak lurus sehingga ikatannya lebih baik dimana pada saat tumbukan terjadi serat yang melingkar penuh memberikan efek tambahan kekuatan lebih terhadap serat yang tegak lurus. Sehingga kekuatan komposit menjadi lebih tinggi karena lebih kaku bila dibandingkan dengan jenis anyaman 2 dan jenis anyaman 3 yang hanya berikatan setengah lingkaran.

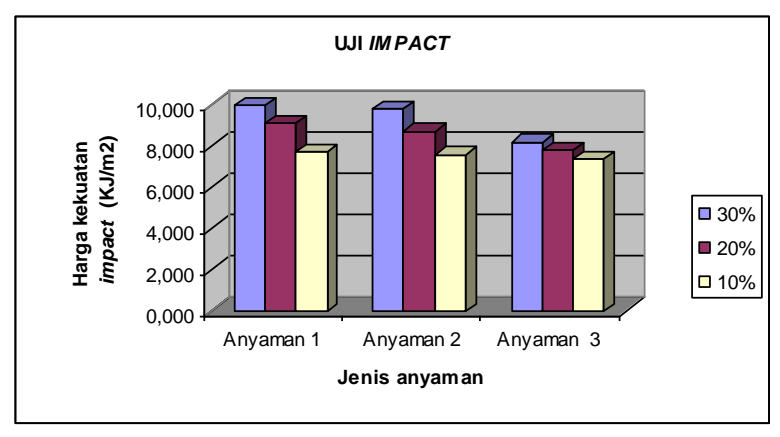

\section{Gambar 7. Grafik hubungan jenis anyaman serat terhadap kekuatan impact.}

Bentuk anyaman melingkar penuh terhadap serat yang tegak lurus pada pengujian impact retakan terjadi melalui daerah pinggiran dari anyaman yang melingkar sehingga aliran retakan menjadi lebih panjang, karena panjangnya aliran retakan energi yang terserap oleh specimen lebih tinggi sehingga harga dari kekuatan impact ikut meningkat

Dengan fraksi volume serat sebesar 30 $\%$ maka jumlah serat yang berada pada specimen semakin banyak pula sehingga dapat disimpulkan matriks sebagai bahan pengikat akan lebih banyak mengikat serat dimana serat sebagai bahan penguat sehingga kekuatan impact akan semakin tinggi. dengan banyaknya serat yang terdapat pada specimen maka jarak antar serat akan semakin menyempit sehingga rongga serat dengan serat yang merupakan matriks semakin berkurang dan lebih getas.

\section{Kekuatan Bending}

Hasil pengujian kekuatan bending dapat dilihat pada Tabel 2 dan grafik hubungan antara jenis anyaman dan fraksi volume serat terhadap kekuatan bending yang ditunjukkan pada Gambar 8 di bawah ini.

Dari grafik Gambar 8 dapat dilihat bahwa kekuatan bending rata-rata tertinggi terjadi pada anyaman 2 dengan fraksi volume serat $30 \%$ memiliki kekuatan bending sebesar $25,92 \mathrm{~N} / \mathrm{mm}^{2}$ dikarenakan anyaman 2. 
Tabel 2. Data kekuatan bending rata-rata.

\begin{tabular}{|c|c|c|c|}
\hline \multirow[t]{2}{*}{$\begin{array}{c}\text { Jenis } \\
\text { anyaman }\end{array}$} & \multicolumn{3}{|c|}{$\begin{array}{c}\text { Kekuatan bending }\left(\mathrm{N} / \mathrm{mm}^{2}\right) \\
\text { variasi fraksi volume serat } \\
(\%)\end{array}$} \\
\hline & $10 \%$ & $20 \%$ & $30 \%$ \\
\hline \multirow{3}{*}{ Anyaman 1} & 16,38 & 20,82 & 23,61 \\
\hline & 15,83 & 21,38 & 24,16 \\
\hline & 16,10 & 22,22 & 23,88 \\
\hline Total & 48,31 & 64,41 & 71,65 \\
\hline \multirow[t]{2}{*}{ Rata-rata } & 16,10 & 21,47 & 23,88 \\
\hline & 21,38 & 23,61 & 26,67 \\
\hline \multirow[t]{2}{*}{ Anyaman 2} & 21,38 & 25,27 & 26,38 \\
\hline & 18,33 & 24,99 & 24,72 \\
\hline Total & 61,08 & 73,87 & 77,77 \\
\hline \multirow[t]{2}{*}{ Rata-rata } & 20,36 & 24,62 & 25,92 \\
\hline & 21,93 & 21,38 & 26,94 \\
\hline \multirow[t]{2}{*}{ Anyaman 3} & 16,65 & 24,99 & 23,61 \\
\hline & 15,54 & 22,22 & 22,22 \\
\hline Total & 54,13 & 68,58 & 72,76 \\
\hline Rata-rata & 18,04 & 22,86 & 24,25 \\
\hline
\end{tabular}

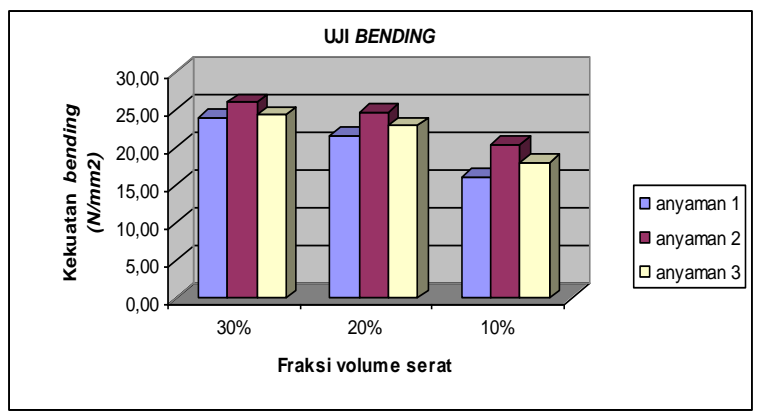

Gambar 8. Grafik hubungan jenis anyaman serat terhadap kekuatan bending.

Pada saat beban diberikan pada pengujian bending menunjukkan ikatan serat dengan serat yang tidak terlalu kaku dan tidak terlalu mulur sebab pada proses pengujian bending dimana beban bending ditempatkan seperti gambar di bawah ini dimana pada saat beban diberikan, serat pada bagian atas dari specimen akan menerima beban tekan sedangkan serat pada bagian bawah akan menerima beban tarik secara perlahan-lahan sehingga serat yang menerima beban tarik akan mengalami pemanjangan atau mulur namun masih menahan beban yang diberikan.

Dari Gambar 8 diatas terlihat bahwa semakin tinggi fraksi volume serat yang diberikan pada specimen akan semakin tinggi pula harga kekuatan bending. Hal ini dikarenakan dengan fraksi volume $10 \%$ jarak antara serat dengan serat semakin renggang dan menyebabkan jumlah serat yang ada dalam specimen berkurang dimana serat berfungsi sebagai penguat dan mereduksi distribusi tegangan yang terjadi, jarak serat dengan serat yang paling rapat dimiliki oleh specimen dengan fraksi volume serat $30 \%$.

Dengan fraksi volume serat $30 \%$ serat yang terikat oleh matrik akan semakin banyak pula sehingga harga kekuatan dari spesimen dengan fraksi volume serat 30\% akan memiliki harga kekuatan yang lebih tinggi dibandingkan dengan harga kekuatan specimen dengan fraksi volume serat $20 \%$ dan $10 \%$.

\section{KESIMPULAN}

Dari hasil penelitian ini maka dapat diperoleh kesimpulan antara lain :

1. Pada pengujian impact jenis anyaman dan fraksi volume serat berpengaruh signifikan terhadap kekuatan impact sedangkan interaksi antara jenis anyaman dan fraksi volume serat ada interaksi tapi tidak berpengaruh signifikan terhadap kekuatan impact.

2. Pada pengujian bending jenis anyaman dan fraksi volume serat berpengaruh signifikan terhadap kekuatan bending sedangkan interaksi antara jenis anyaman dan fraksi volume serat ada interaksi tapi tidak berpengaruh signifikan terhadap kekuatan bending

3. Pada pengujian impact menunjukkan kekuatan impact tertinggi terjadi pada jenis anyaman 1 dengan fraksi volume serat $30 \%$ didapatkan nilai rata-rata sebesar 9,91 $\mathrm{KJ} / \mathrm{m} 2$, sedangkan kekuatan terendah terjadi pada jenis anyaman 3 dengan fraksi volume serat $10 \%$ didapatkan nilai rata-rata sebesar $7,35 \mathrm{KJ} / \mathrm{m} 2$.

4. Pada pengujian bending menunjukkan bahwa nilai rata-rata kekuatan bending paling tinggi terjadi pada anyaman 2 dengan fraksi volume serat $30 \%$ didapatkan nilai rata-rata sebesar 25,92 N/mm2, sedangkan kekuatan bending terendah terjadi pada jenis anyaman 1 dengan fraksi volume serat $10 \%$ didapatkan nilai rata-rata sebesar $16,10 \mathrm{~N} / \mathrm{mm} 2$.

\section{DAFTAR PUSTAKA}

Anonim, 1998, Annual Book ASTM Standar, USA.

Feldman, D., dan Hartomo, J.A., 1995, Bahan Polimer Konstruksi Bangunan, Gramedia Pustaka Utama.

Hartomo, J.A., Rusdiharsono, A., Hardianto, D., 1992, Memahami Polimer Dan Pereka, Andi Offset Yogyakarta. 
Supratman A.W, 2009, Pengaruh Konsentrasi

Larutan $\mathrm{NaOH}$ Pada Perlakuan

Permukaan Serat Terhadap Kekuatan

Impact Dan Bending Komposit Serat

Searah Epoxy Yang Diperkuat Serat

Alam (Boehmeria Nivea (L) Gaud),

Skripsi, Universitas Mataram, Mataram. 